\title{
Hubungan Pengetahuan dan Sikap Ibu dengan Kelengkapan Kunjungan Antenatal Care di Puskesmas Kenten Palembang Tahun 2019
}

\author{
Dewi Ciselia $^{1}$, Vivi Oktari ${ }^{2}$ \\ Prodi DIII Kebidanan Stikes Pembina Palembang ${ }^{1,2}$
}

Informasi Artikel

Diterima : 12 November 2020

Direvisi : 17 November 2020

Disetujui : 01 Desember 2020

*Korespondensi Penulis : dewiciselia@gmail.com vivioktari26@gmail.com

\section{A B S T R A K}

Program kesehatan ibu dan anak diberi kode angka $\mathrm{K}$ yang merupakan singkatan dari kunjungan. Dikatakan K1 murni jika minimal dilakukan sekali kunjungan hingga usia kehamilan 28 minggu. Dikatakan kunjungan sesuai standar K4 dimana paling sedikit dilakukan 4 kali selama kehamilan, satu kali pada trimester pertama, satu kali pada trimester kedua, dua kali pada trimester ketiga. Jenis penelitian yang dilakukan adalah penelitian analitik dengan pendekatan cross sectional. Penelitian dilakukan pada bulan November-Desember 2019 di Puskesmas Kenten Palembang tahun 2019. Sampel yang digunakan sebanyak 30 orang. Teknik pengambilan sampel pada penelitian ini dilakukan secara purposive sampling, yaitu dimana sampel diambil sesuai dengan karakteristik tertentu. Pada hasil penelitian menunjukkan Kelengkapan kunjungan ibu hamil dalam melakukan $A N C$ yang teratur yaitu $(56,7 \%)$, Ibu hamil mempunyai pengetahuan baik tentang $A N C$ $(73,3 \%)$, ibu hamil yang memiliki sikap yang baik tentang $A N C$ $(66,7 \%)$, Hasil uji statistik Variabel pengetahuan dengan kelengkapan kunjungan di peroleh hasil nilai $p$ value $>0,05$ yaitu 0.698. bgitu juga pada hasil uji statistik variabel sikap dengan kelengkapan kunjungan diperoleh hasil nilai $p$ value $>0.05$ yaitu 0,698 . Tidak ada hubungan pengetahuan ibu dengan tingkat keteraturan melakukan kelengkapan kunjungan antenatal care. Tidak ada hubungan sikap ibu dengan kelengkapan kunjungan antenatal care di Puskesmas Kenten Palembang Tahun 2019.

Kata Kunci : Kelengkapan Kunjungan ANC, Pengetahuan, Sikap

\section{ABSTRACT}

Maternal and child health programme are given a numeric code " $K$ " which stands for visit. Only $K 1$ if the antenatal visit at least once a visit until 28 weeks of gestation. It is said that the visits according to the K4 standard are carried out at least 4 times during pregnancy, once in the first trimester, once in the second trimester, twice in the third trimester. This type of research is analytic research with a cross sectional approach. The research was conducted in November-December 2019 at the Puskesmas Kenten Palembang in 2019. The samples were selected using the purposive sampling technics, that the sample are taken according to certain caractristics, 30 prgnant women involved in this study. The result of the study showed that the completeness of antenatal visit is (56.7\%), the knowledge of pregnant women was good $(73,3 \%)$, they had a favorable attitude $(66,7 \%)$. Statistical variable test showed with the same $P$ value $>0,05(0,698)$ of preganant womn'attitude and preganant women's behavior that there is no relationship between completenees of antenatal visit with the knowlage and the attitude of pregnant women in Pusksmas Kenten Palembang 2019

Keywords: Antenatal visit, attitude, knowledge, Pregnancy 
Jurnal Kebidanan :Jurnal Medical Science Ilmu Kesehatan Akademi Kebidanan Budi Mulia Palembang Volume.10 No.2, Desember 2020

\section{PENDAHULUAN}

Antenatal care atau pemeriksaan kehamilan diartikan sebagai pengawasan sebelum persalinan terutama ditujukan pada pertumbuhan dan perkembangan janin dalam rahim. (Anonim,2013). Tujuan Antenatal care adalah mempersiapkan ibu hamil, fisik, psikologis dan sosial dalam menghadapi masa kehamilan, persalinan, nifas dan masa menyusui serta mengupayakan bayi yang dilahirkan sehat, kesiapan menghadapi komplikasi dalam kehamilan dan menanggulanginya. Sedini mungkin jika ada penyimpangan atau komplikasi selama hamil dapat ditangani (AB Saifuddin, 2015).

Cakupan K1 dan K4 untuk kota palembang tahun 2014 sebesar 99,84\% dan K4 sebesar 96,64\%. Cakupan K1 terendah terdapat di Kecamatan Sako $(98,1 \%)$ dan tertinggi di Kecamatan Gandus, Seberang Ulu 1, Kertapati, Plau, Bukit Kecil, Ilir Timur II, dan Alang Alang Lebar (100\%). Sedangkan cakupan K4 tertinggi terdapat Kecamatan Sako $(99,79 \%)$ dan terendah di Kecamatan Sematang Borang (86,33\%). (Profil Dinkes Kota Palembang, 2016).

\section{METODE PENELITIAN}

Jenis penelitian yang dilakukan adalah penelitian analitik dengan pendekatan cross sectional. Pengukuran variabel dilakukan pada suatu saat artinya subyek diobservasi dan dilakukan pengukuran pada saat yang sama.

Populasi penelitian adalah semua ibu hamil normal yang melakukan kunjungan antenatal care di wilayah kerja Puskesmas Kenten Palembang tahun 2019 (januari-Desember) sebanyak 598 orang (Sudigdo, 2015).

Sampel pada penelitian ini adalah ibu hamil normal trimester III yang melakukan kunjungan antenatal care di Puskesmas Kenten Palembang. Sampel yang digunakan sebanyak 30 orang.

Pengambilan sampel pada penelitian ini menggunakan teknik Purposive Sampling yaitu metode pengambilan sampel dengan memilih siapa yang kebetulan ada atau dijumpai.

\section{HASIL PENELITIAN}

A. Variabel Dependent

Tabel 1.Distribusi frekuensi kunjungan ibu tentang kelengkapan antenatal care di wilayah kerja Puskesmas Kenten Palembang Tahun 2019.

\begin{tabular}{lcc}
\hline $\begin{array}{c}\text { Kelengkapan } \\
\text { Kunjungan } \\
\text { ANC }\end{array}$ & Jumlah (n) & Persentase \% \\
\hline Lengkap & 17 & $56,7 \%$ \\
\hline Tidak Lengkap & 13 & $43,3 \%$ \\
\hline Jumlah & $\mathbf{3 0}$ & $\mathbf{1 0 0}$ \\
\hline \multicolumn{1}{c}{ Berdari }
\end{tabular}

Berdasarkan tabel 1 dapat diketahui dari 30 responden didapatkan ibu yang melakukan kunjungan antenatal care sebanyak 17 responden $(56,7 \%)$ lebih dari jika dibandingkan dengan responden yang tidak teratur mendapatkan kunjungan antenatal care yaitu 13 responden $(43,3 \%)$.

\section{B. Variabel Independent \\ 1. Pengetahuan}

Variabel pengetahuan terbagi menjadi 2 kategori yaitu tingkat pengetahuan baik bila jawaban responden benar 75\%-100\% dari keseluruhan pertanyaan, tingkat pengetahuan responden kurang jika jawaban yang benar $<75 \%$ dari keseluruhan pertanyaan. Data distribusi mengenai pengetahuan responden dapat dilihat pada tabel berikut :

Tabel 2. Hubungan Pengetahuan dengan Kelengkapan Kunjungan Antenatal Care di Wilayah Puskesmas Kenten Palembang Tahun 2019

\begin{tabular}{|c|c|c|c|c|c|c|c|}
\hline \multirow{3}{*}{ Pengetahuan } & \multicolumn{4}{|c|}{ Kunjungan ANC } & \multirow{2}{*}{\multicolumn{2}{|c|}{ Total }} & \multirow{3}{*}{$\begin{array}{c}P \\
\text { Value }\end{array}$} \\
\hline & \multicolumn{2}{|c|}{ Lengkap } & \multicolumn{2}{|c|}{$\begin{array}{c}\text { Tidak } \\
\text { Lengkap }\end{array}$} & & & \\
\hline & $\mathrm{n}$ & $\%$ & $\mathrm{n}$ & $\%$ & $\mathrm{n}$ & $\%$ & \\
\hline Baik & 13 & 59,1 & 9 & 40,9 & 22 & 100 & \\
\hline Kurang Baik & 4 & 50 & 4 & 50 & 8 & 100 & 0,698 \\
\hline Total & 17 & 56,7 & 13 & 43,3 & 30 & 100 & \\
\hline
\end{tabular}

Berdasarkan tabel diatas dapat diketahui dari 30 responden yang pengetahuan baik berjumlah 22 responden $(73,3 \%)$, responden yang berpengetahuan kurang 8 responden $(26,7 \%)$. Hasil uji statistik dengan menggunakan uji chi square menunjukkan didapatkan nilai pvalue $>0.698$, sehingga dikatakan bahwa tidak ada hubungan antara pengetahuan ibu dengan kunjungan ANC di wilayah kerja Puskesmas Kenten Palembang.

\section{Sikap}

Variabel sikap dikelompokan menjadi dua kategori, yaitu baik dan kurang baik. Baik jika nilai mean $\geq 23$ dan yang tidak baik nilai mean $\leq$ 23. 
Tabel 3. Hubungan Sikap Ibu dengan Kelengkapan Kunjungan

Antenatal Care di Wilayah Puskesmas Kenten Palembang Tahun 2019

\section{Kunjungan ANC}

\begin{tabular}{|c|c|c|c|c|c|c|c|}
\hline \multirow{3}{*}{ Sikap Ibu } & \multicolumn{4}{|c|}{ Kunjungan ANC } & \multirow{2}{*}{\multicolumn{2}{|c|}{ Total }} & \multirow{3}{*}{$\begin{array}{c}P \\
\text { Value }\end{array}$} \\
\hline & \multicolumn{2}{|c|}{ Lengkap } & \multicolumn{2}{|c|}{$\begin{array}{c}\text { Tidak } \\
\text { Lengkap }\end{array}$} & & & \\
\hline & $\mathrm{n}$ & $\%$ & $\mathrm{n}$ & $\%$ & $\mathrm{n}$ & $\%$ & \\
\hline Baik & 13 & 59,1 & 9 & 40,9 & 22 & 100 & \\
\hline Kurang Baik & 4 & 50 & 4 & 50 & 8 & 100 & 0,698 \\
\hline Total & 17 & 56,7 & 13 & 43,3 & 30 & 100 & \\
\hline
\end{tabular}

Berdasarkan tabel diatas diketahui dari 30 responden dengan sikap baik berjumlah 22 responden $(73,3 \%)$, responden yang memiliki sikap kurang baik sebanyak 8 responden $(26,7 \%)$.

Hasil dari uji statistik dengan menggunakan chi square, diperoleh nilai pvalue $>0,698$, ini bererti bahwa tidak ada hubungan antara sikap ibu dengan kelengkapan kunjungan ibu dalam melakukan pemeriksaan ANC

\section{PEMBAHASAN}

Penelitian ini dilakukan sebagai upaya meningkatkan jumlah kunjungan antenatal care. Penelitian ini dilakukan pada bulan November sampai dengan desember 2019 di Wilayah Kerja Puskesmas Kenten Palembang. Adapun sampel dalam penelitian ini adalah ibu hamil trimester tiga yang memeriksakan kehamilannya di wilayah kerja Puskesmas Kenten Palembang priode 01 November sampai dengan 31 Desember yang berjumlah 30 orang.

Dalam penelitian ini variabel Variabel kelengkapan kunjungan antenatal care di kelompokan menjadi dua kategori, yaitu : lengkap dan tidak lengap. Lengkap jika ibu melakukan kunjungan antenatal care sesuai standar K4 ( $\geq 4$ kali), dan tidak lengkap jika ibu tidak melakuan kunjungan antenatal care sesuai standar ( $\leq 4$ kali). Dari hasil penelitian ini menunjukan bahwa dari 30 responden yang melakukan kunjungan lengap yaitu berjumlah 17 responden $(56,7.0 \%)$ lebih banyak dibandingkan dengan responden yang tidak melakukan kunjungan tidak lengkap yaitu berjumlah 13 responden $(43,3 \%)$.

Berdasarkan hasil penelitian dapat disimpulkan bahwa sebagian besar responden yang melakukan kunjungan ANC lengkap yaitu berjumlah 17 responden $(56,7 \%)$ sedangkan yang tidak melakukan kunjungan ANC yaitu berjumlah 13 responden $(43,3 \%)$.

Berdasarkan dari hasil diatas maka peneliti berasumsi Ibu-Ibu Hamil yang melakukan kelengkapan kunjungan antenatal care lengkap, dikarenakan kunjungan antenatal care lengkap sangat berperan penting bagi Ibu dan Janinnya yaitu untuk melihat pertumbuhan dan perkembangan janin, dari 13 Orang masih ada yang tidak melakukan Kunjungan ANC lengkap berkemungkinan Ibu-Ibu Hamil tersebut menjalanni kesibukkan karena bekerja, sakit atau kurangnya pengetahuan pentingnya Kunjungan ANC sehingga tidak melakukan Kelengapan Kunjngan Antenatal Care selama Kehamilan.

\section{Pengetahuan}

Dalam penelitian ini variabel indenpenden (pengetahuan) dibagi menjadi dua kategori yaitu pengetahuan baik, dan pengetahuan kurang. Baik yaitu jika ibu menjawab pertayaan benar 75\%$100 \%$,dan pengetahuan kurang jika ibu menjawab pertayaan dengan benar $<75 \%$. (Arikunto, 2014).

Hasil pengetahuan ini menujukan bahwa dari 30 responden yang berpengetahuan baik yaitu sebanyak 22 responden (73,3\%), sedangkan yang berpengetahuan kurang sebanyak 8 Responden (26.7\%),

Hasil uji statistik dengan menggunakan uji chi square menunjukkan didapatkan nilai pvalue $>0.698$, sehingga dikatakan bahwa tidak ada hubungan antara pengetahuan ibu dengan kunjungan ANC di wilayah kerja Puskesmas Kenten Palembang.

Dari hasil penelitian yang dilakukan maka peneliti berasumsi bahwa tingkat Pengetahuan ibu tidak mempengaruhi Kelengkapan Kunjungan ANC, mengingat banyak fator lain yang lebih berpengaruh dari kelengkapan kunjungan antenatal care di antaranya berpindahnya tempat pemeriksaan antenatal care ibu tesebut yang tidak dilaporkan ke pihak Puskesmas Kenten.

\section{Sikap}

Sikap merupakan besarnya perasaan positif dan negatif terhadap suatu objek (favorable) atau negative (unvorable) terhadap suatu objek, orang, institusi, atau kegiatan. Eagly dan Caiken (2015) dalam Aiken (2014) mendefinisikan sikap sebagai kecenderungan psikologi yang diekpresikan dengan mengevaluasi suatu entitas dalam derajat suka dan tidak suka. Sikap di pandang sebagai suatu yang efektif atau evaluative (Nursalam, 2015).

Pada penelitian ini variabel independen (sikap) dibagi menjadi dua kategori yaitu baik dan tidak baik. Baik jika nilai mean $\geq 23$ sedangan tidak baik nilai mean $\leq 23$. Berdasarkan dari hasil penelitian yang telah dilakukan bahwa dari 30responden didapatkan responden memiliki 
Jurnal Kebidanan :Jurnal Medical Science Ilmu Kesehatan Akademi Kebidanan Budi Mulia Palembang Volume.10 No.2, Desember 2020

sikap baik yaitu sebanyak 22 responden $(73,3 \%)$, lebih banyak jika dibandingkan dengan yang sikap tidak baik sebanyak 8 Responden $(26,7 \%)$.

Hasil dari uji statistik dengan menggunakan chi square, diperoleh nilai pvalue $>0,698$, ini bererti bahwa tidak ada hubungan antara sikap ibu dengan kelengkapan kunjungan ibu dalam melakukan pemeriksaan ANC.

Dari hasil penelitian yang dilakukan maka peneliti berasumsi bahwa sikap ibu tidak mempengaruhi Kelengkapan Kunjungan ANC, sikap pibu hamil yang baik yang mendukung terhadap kelengkapan kunjungan antenatal mungkin tertutupi oleh kemungkinan ibu tidak melaporkan saat ibu memeriksakan kehamilannya di dokter spesialis atau pelayanan kesehtan lainnya

\section{KESIMPULAN DAN SARAN \\ Kesimpulan}

Hasil dari uji satistik chi-squeare didapatkan $\mathrm{p}$ value $=0,698>\alpha=0.05$, yang jika dibandingkan dengan nilai $\alpha=0,05$, maka $p$ value $\leq 0,05$ ini berarti tidak ada hubungan yang bermakna antara pengetahuan Ibu dengan kelengkapan kunjungan antenatal care di Puskesmas Kenten Palembang Tahun 2019. Hasil dari uji satistik chi-squeare didapatkan $\mathrm{p}$ value $=0,698>\alpha=0.05$, yang jika dibandingkan dengan nilai $\alpha=0,05$, maka $p$ value $\leq 0,05$ ini berarti tidak ada hubungan yang bermakna antara sikap Ibu dengan kelengkapan kunjungan antenatal care di Puskesmas Kenten Palembang Tahun 2019.

Saran

Dengan tidak di dapatkannya hubungan yang bermakna antara sikap serta pengetahuan ibu hamil terhadap kelengkapan kunjungan antenatal care, maka sebaiknya dilakukan penelitian pada faktor lainnya guna meningkatkan jumlah kelengkapan kunjungan antnatal care.

\section{DAFTAR PUSTAKA}

Arikunto, S. 2014. Prosedur Penelitian Suatu Pendekatan Praktik (Edisi Revisi). Jakarta : Rineka Cipta

Anonim.2013. Pengertian Antenatal care $(A N C)$.(Online:www.Sarjanaku.com/201 3/Pengertian-antenatal-care-ANC.shtml). Diakses tanggal 22 Maret, 2017.
Bartini, istri, 2015. Asuhan Kebidanan Pada Ibu Hamil Normal (ASKEB). Yogyakarta: Nuha Medika

Buston, Helen.2016. Miwefery Essentials. Jakarta: EGC

Dinas Kesehatan Provinsi Sumatera Selatan. 2016. Profil Dinas Kesehatan Provinsi Sumatera Selatan 2015.

Kemenkes, RI.2015.Profil-Kesehatan-Indonesia2015.pdf

Madriwati, M.Kes. 2015. Asuhan Kebidanan Antenatal. Jakarta:EGC

Notoatmodjo, S. 2015. Promosi Kesehatan dan Ilmu Perilaku. Jakarta: Rhineka Cipta

Nursalam.2015. Metodologi Penelitian IlmuKeperawatan. Jakarta: Salemba Medika

Nurul Ramadani.2010."Hubungan antara Frekuensi Antenatal Care dengan Kematian Perinatal di RSUD Dr. Moewardi. Jurnal : Surakarta

Okzan, I.A. \& Mete, S .2015. Pregnancy Planning and Antenatal Health Behaviour: Findings from one maternity unit in Turkey. Mindwifery February(18):1-10

Panilawati, Ika Saryono.2015. Asuhan Kebidanan 1 (Kehamilan). Yogyakarta: Nuha Medika.

Rukiah, A.Y, dkk.2015. Asuhan Kebidanan Kehamilan. Jakarta: CV.Trans Info Medika

Saifuddin, AB. 2015. Ilmu Kebidanan. Jakarta: PT. Bina Pustaka Sarwono Prawirohardjo

Sastroasmoro, Sudigdo.2015. Dasar-Dasar Metodologi Penelitian Klinis. Jakarta: Sagung Seto

Sudigdo, S, 2015. Metodologi Penelitian Pendidikan. Bandung : PT Alfabet

Wawan, A.2016. Teori Pengukuran Pengetahuan, Sikap dan Perilaku Manusia. Yogyakarta: Nuha Medika 
Jurnal Kebidanan :Jurnal Medical Science Ilmu Kesehatan Akademi Kebidanan Budi Mulia Palembang Volume.10 No.2, Desember 2020 
